\title{
New insigths on the metabolic diversity among the epibiotic microbial communitiy of the hydrothermal shrimp Rimicaris exoculata
}

\author{
Magali Zbinden ${ }^{a},{ }^{*}$, Bruce Shillito ${ }^{a}$, Nadine Le Bris ${ }^{b}$, Constance de Villardi de Montlaur ${ }^{a}$, \\ Erwan Roussel $^{c}$, François Guyot ${ }^{d}$, Françoise Gaill ${ }^{a}$ and Marie-Anne Cambon-Bonavita ${ }^{c}$
}

\footnotetext{
a UMR CNRS 7138, Systématique, Adaptations et Evolution, UPMC, 7 Quai Saint Bernard, 75252 Paris cedex 05, France

${ }^{\mathrm{b}}$ Ifremer Brest, Département Environnement Profond, BP 70, 29280 Plouzané, France

c Ifremer Brest, Laboratory of Microbiology of Extreme Environments, LM2E, UMR 6197, BP 70, 29280 Plouzané, France

d Institut de Physique du Globe de Paris, Laboratoire de Minéralogie-Cristallographie, Université Paris-Jussieu, Tour 16, Case 115, 4, place Jussieu, 75252 Paris Cedex 05, France
}

\author{
*: Corresponding author : M. Zbinden, Tel.: +33 1442735 02; fax: +33 14427 52 50, email address : \\ magali.zbinden@snv.jussieu.fr
}

\begin{abstract}
:
The Rimicaris exoculata dominates the megafauna of some of the Mid Atlantic ridge hydrothermal vent sites. This species harbors a rich community of bacterial epibionts inside its gill chamber. Literature data indicate that a single 16S rRNA phylotype dominates this epibiotic community, and is assumed to be a sulfide-oxidizing bacteria. However attempts of cultivation were not successful and did not allow to confirm it. The aim of our study was to test the hypothesis of sulfide oxidation in the gill chamber, by a multidisciplinary approach, using in vivo experiments at in situ pressure in the presence of sulfide, microscopic observations and a molecular survey. Morphology of microorganisms, before and after treatment, was analyzed to test the effect of sulfide depletion and re-exposure. Our observations, as well as molecular data indicate a wider diversity than previously described for this shrimp's epibiotic community. We observed occurrence of bacterial intracellular sulfur- and iron-enriched granules and some methanotrophic-like bacteria cells for the first time. Genes that are characteristic of methaneoxidizing $(p m O A)$ and sulfide-oxidizing (APS) bacteria were identified. These results suggest that three metabolic types (iron, sulfide and methane oxidation) may co-occur within the epibiont community associated with Rimicaris exoculata. As this shrimp colonizes chemically contrasted environments, the relative abundance of each metabolic type could vary according to the local availability of reduced compounds.
\end{abstract}

Keywords: High pressure experiments; Hydrothermal vent shrimp; Intracellular granules; Iron; Methane; Sulfur

\section{Introduction}


Hydrothermal vent communities along the Mid-Atlantic Ridge (MAR) are dominated by large populations of caridean shrimps. Found in dense clusters of 40000 individuals per $\mathrm{m}^{3}$ (Segonzac et al., 1993), Rimicaris exoculata is the most abundant species on some of these sites. This shrimp has been found to host a dense bacterial epibiosis on the internal walls (branchiostegites) of its branchial chamber and on its mouthparts (scaphognathites and exopodites of the first maxillipeds) (Van Dover et al., 1988; Casanova et al., 1993; Segonzac et al. 1993; Zbinden et al., 2004). This indicates an intimate association between these organisms. The main source of dietary carbon could originate: 1) from bacteria ingested with the sulfide scraped from the chimney (Van Dover et al., 1988), 2) from their epibiotic bacteria (Segonzac et al., 1993; Gebruk et al., 2000) or 3) from an autotrophic bacterial population living in the shrimp's gut (Pond et al., 1997; Polz et al., 1998; Zbinden and CambonBonavita, 2003). Fatty acid abundances and carbon isotopic composition recently provided strong evidence that mature $R$. exoculata gain most of their carbon from the epibiotic bacteria within their carapace rather than from bacteria grazed on the chimney walls (Rieley et al., 1999). For shrimps sampled from the Snake Pit site, three bacterial morphotypes were described (Segonzac et al., 1993) which all belonged to the same phylotype of Epsilonproteobacteria (Polz and Cavanaugh, 1995). Although attempts to cultivate these microorganims failed until now, they were hypothesized to acquire their metabolic energy from sulfide oxidation (Gebruk et al. 1993; Wirsen et al., 1993). Chemosynthetic activity of the filamentous bacteria from the inner cephalothorax surface has been shown (Wirsen et al., 1993), but no significant increase of $\mathrm{CO}_{2}$ incorporation was observed in the presence of reduced sulfur compounds (Polz et al., 1998). 
More recently, Zbinden et al. (2004) suggested that another metabolic pathway, iron oxidation, could be involved at the iron-rich Rainbow ultramafic site. Unlike most active hydrothermal sites known to date, the hydrothermal circulation at Rainbow is hosted on mantle rocks. As a result, its fluid composition departs from the common range of hydrothermal end-members, and is relatively depleted in $\mathrm{H}_{2} \mathrm{~S}$ and enriched in $\mathrm{H}_{2}$, FeII and $\mathrm{CH}_{4}$, as a result of the serpentinization processes (Charlou et al., 2002; Douville et al., 2002). During the ATOS cruise, shrimps were all collected from the Rainbow site. The main objective of our work was to test the hypothesis that all the shrimp epibionts were sulfideoxidizers. To overcome the inhability to cultivate the epibionts, we performed in vivo experiments. For the first time, pressurized aquaria were used to gain information on the bacterial epibionts' metabolism. The aspect and ultrastructure of the bacteria were checked after incubations at 230 bars (in situ pressure), at $15^{\circ} \mathrm{C}$ (in situ temperature) with or without sulfide-enriched seawater (thereafter called sulfide pulses), and compared to in situ reference shrimps. A molecular survey was undertaken to get new insights on possible metabolic type of the epibiotic microbial communities of Rimicaris exoculata, particularly thiotrophy using the 5'-adenylylsulfate (APS) reductase gene.

\section{Materials and methods}

\subsection{Animal collection and selection}

Specimens of Rimicaris exoculata were collected during the French ATOS cruise (June 2001), on the Rainbow vent site ( $36^{\circ} 14.0^{\prime}$ N, Mid-Atlantic Ridge, 2320 meter depth).

Shrimps were collected with the suction sampler of the ROV "Victor 6000", operated from the R/V "L'Atalante". Once on board, some live specimens were immediately dissected into 
body components. These samples are referred to as "reference shrimps" further in the text. Alternatively, some shrimps were placed in pressure vessels (IPOCAMPTM) for in vivo experiments (see below) and in this case dissected immediately after removal from the vessel. Scaphognathite samples were fixed in a 2.5\% glutaraldehyde - sodium cacodylate buffered solution and later post-fixed in osmium tetroxide for morphological observations. Samples for X-ray analyses were not postfixed. For each treatment, shrimps in anecdysis were selected for observation according to the moult-staging method of Drach and Tchernigovtzeff (1967), by examination of bristle-bearing appendages (uropods) under a light microscope. The moulting stage was later confirmed by examination of the branchiostegite integument by light microscopy and Transmission Electron Microscopy (TEM). For molecular studies, shrimps were frozen immediately after recovery under sterile conditions. Once in the lab, the scaphognathites and branchiostegites were dissected and DNA extraction was performed.

\subsection{Pressurized incubator IPOCAMPTM}

The stainless steel pressure vessel has an internal volume of approximately 19 liters (see Shillito et al., 2001 for detailed description and diagrams). This is a flow-through pressure system, with flow rates that can reach $201 . h^{-1}$. Pressure oscillations arising from pump strokes (100 rpm) are less than 1 bar at working pressure. The temperature of the flowing seawater (filtered at $1 \mu \mathrm{m}$ mesh) is constantly measured, at pressure, in the inlet and outlet lines $\left( \pm 1^{\circ} \mathrm{C}\right.$ ). Temperature regulation is powered by a regulation unit (Huber CC 240) that circulates ethylene-glycol through steel jackets surrounding the pressure vessel and around the seawater inlet line. 
In vivo experiments. Re-pressurization at 230 bars was achieved in about 2 min after closure

of the vessel. As the shrimps were sampled at the end of the dive, less than $2 \mathrm{~h}$ passed between the time the samples began decompression (submersible ascent) and the moment they were re-pressurized. At atmospheric pressure, just after the submersible recovery, the shrimps (except for some individuals, which may have been damaged by the suction sampler) were alive and active. Pressure vessel experiments were carried out at in situ pressure (230 bars) and at $15^{\circ} \mathrm{C}$, according to the literature data: $10-15^{\circ} \mathrm{C}$ (Segonzac et al., 1993) ; 3.8$14.7^{\circ} \mathrm{C}$ (Zbinden et al., 2004) ; $13.2 \pm 5.5^{\circ} \mathrm{C}$ (Desbruyères et al., 2001). Previous in vivo experiments showed a good physiological state of the shrimps when re-pressurized at these temperature and pressure conditions (Ravaux et al., 2003). Only alive and active shrimps after treatment were used for the present study.

Two experiments at 230 bars were performed:

(1) Sample incubation at $15^{\circ} \mathrm{C}$ in surface seawater, to investigate the effect of depletion of electron donors on the shrimps and their epibionts. Twelve shrimps were placed in the pressure vessel, for $30 \mathrm{~h}$. The seawater was regularly (5 times) renewed, by replacing a quarter of the total volume. Surface seawater oxygen level $(253 \mu \mathrm{M})$ lies slightly above the concentration measured in the environment of the shrimps (Schmidt et al., 2008). These samples are referred to as "non-sulfide shrimps" further in the text.

(2) Incubation at $15^{\circ} \mathrm{C}$, with exposure to sulfide pulses. Nine shrimps were placed in the pressure vessel for $32 \mathrm{~h}$. During the $32 \mathrm{~h}$ of the experiment, we first maintained the shrimps in normal sea-water for 8 hours. Then, 4 pulses were performed as follows : i) the inlet of the flow-through pressure system was fed with a reservoir containing 201 of a solution of $25 \mu \mathrm{M}$ sulfide in natural surface seawater. This concentration roughly corresponds to the maximum 
of estimated from the shrimps environment at Rainbow (Schmidt et al., in press). This moderate concentration also ensured that the oxygen is not fully depleted from the medium.

When the reservoir was almost empty, the outlet line was connected to the inlet line, in order to recirculate the sulfide-enriched seawater; ii) After an exposure of one hour, seawater was then pumped into the vessel for $2 \mathrm{~h}$; iii) finally the vessel was closed for $3 \mathrm{~h}$ before the next pulse started with a freshly prepared $25 \mu \mathrm{M}$ sulfide solution. These samples are referred to as "sulfide shrimps" further in the text. The term "re-pressurised shrimps" englobes both "non sulfide" and "sulfide" shrimps.

Survival of the re-pressurized shrimps was determined at the end of the pressure experiments, by identifying each individual and witnessing its movements.

\subsection{Light microscopy and transmission electron microscopy (TEM)}

Samples were dehydrated in ethanol and propylene oxide series and then embedded in an epoxy resin (Serlabo). Semi-thin and ultra-thin sections were made on a Reichert-Jung Ultramicrotome (Ultracut E) using a diamond knife. Semi-thin sections were stained with toluidine blue for observations by light microscopy (using a Nikon Optiphot-pol microscope and a Zeiss Opton photomicroscope). For ultrastructural observations, thin sections were laid on copper grids and stained with uranyl acetate and lead citrate. Observations were carried out on a Philips 201 TEM, operating at $80 \mathrm{kV}$.

\subsection{Energy dispersive X-ray microanalyses (EDX)}

Microanalysis was carried out using a JEOL JEM 2100F transmission electron microscope, operating at $200 \mathrm{kV}$, and acquired with an energy dispersive X-ray detection system (Tracor 
$5400 \mathrm{FX})$, equipped with a $\mathrm{Si}(\mathrm{Li})$ diode, using a $2.4 \mathrm{~nm}$ probe.

\subsection{Ultrastructural analyses and enumeration of bacteria}

Exhaustive analysis and enumeration of bacteria and their intracellular granules were undertaken on one individual for each treatment. For each shrimp, bacteria associated to 5 setae of the scaphognathite were analyzed. For each seta, an overall picture was taken and picture of all the bacteria were then captured at a magnification of 20000. Bacteria cells were then counted and described. The occurrence of intracellular granules was noted for each cell. Granules were defined as electron-dense spots larger than $1.5 \mathrm{~mm}$ on the pictures (i.e. $75 \mathrm{~nm}$ ), as numerous dark spots of various sizes occur in the cells. Due to their small size, spots smaller than $75 \mathrm{~nm}$ cannot be analyzed by EDX and were not taken into account in this study because of the uncertainty on their nature.

\subsection{Statistical analyses}

A one-way ANOVA was used to test differences in the state of the bacteria (i.e. percentage of full granules) among treatments. Normality was judged visually from normal probability plots and homogeneity of variances was verified with the Levene test. A multiple range test using the Student-Newman-Keuls (SNK) procedure was performed to investigate the difference between treatments for significant results. All data analyses were carried out using Statistica v. 6 software.

\subsection{DNA extraction}


One in situ reference shrimp was dissected under sterile conditions. DNAs from scaphognathite (SC) and branchiostegite (LB), were extracted using the FastDNA SPIN kit for soil samples (Bio 101 System, Qbiogen) following the kit protocols.

\subsection{PCR and cloning}

PCR were performed using the universal primers for Bacteria or Archaea 16S rDNA on both (SC and LB) extracted DNA samples: E8F (AGA GTT TGA TCA TGG CTC AG) and U1492R (GTT ACC TTG TTA CGA CTT) for Bacteria and A8F (CGG TGG ATC CTG CCG GA) and A1492R (GGC TAC CTT GTT ACG ACT T) for Archaea. PCR cycles were as follows : 1 cycle of $3 \mathrm{~min}$ at $94^{\circ} \mathrm{C}, 30$ cycles of $1 \mathrm{~min}$ at $94^{\circ} \mathrm{C}, 1 \mathrm{~min} 30$ at $49^{\circ} \mathrm{C}$ and $2 \mathrm{~min}$ at $72^{\circ} \mathrm{C}$ and 1 cycle of 6 min at $72^{\circ} \mathrm{C}$.

The gene encoding particulate methane monooxygenase subunit $\mathrm{A}(p m o A)$ was amplified on the SC DNA using the primers described by Duperron et al. (2007) A189F ( GGN GAC TGG GAC TTC TGG ) and MB661R (CG GMG CAA CGT CYT TAC C ). PCR cycles were as follows : 1 cycle of 4 min at $92^{\circ} \mathrm{C}, 30$ cycles of $1 \mathrm{~min}$ at $92^{\circ} \mathrm{C}, 1 \mathrm{~min} 30$ at $55^{\circ} \mathrm{C}$ and 1 min at $72^{\circ} \mathrm{C}$ and 1 cycle of 9 min at $72^{\circ} \mathrm{C}$.

The gene encoding the APS reductase gene was amplified on the SC DNA using the primers designed before (Blazejak et al., 2006). PCR cycles were as follows : 1 cycle of 4 min at $92^{\circ} \mathrm{C}, 30$ cycles of $1 \mathrm{~min}$ at $92^{\circ} \mathrm{C}, 1 \mathrm{~min} 30$ at $58^{\circ} \mathrm{C}$ and $1 \mathrm{~min}$ at $72^{\circ} \mathrm{C}$ and 1 cycle of $9 \mathrm{~min}$ at $72^{\circ} \mathrm{C}$.

Approximately $100 \mathrm{ng}$ of bulk DNA was amplified in a $50 \mu \mathrm{l}$ reaction mix containing (final concentration) : 1X Taq DNA polymerase buffer (Q biogen Starsbourg, France), $2 \mu \mathrm{M}$ of each dNTP, $20 \mu \mathrm{M}$ of each primer and 2.5U of Taq DNA polymerase (Q Biogen France). PCR products were then visualized on an agarose gel containing ethidium bromide before cloning. The PCR products were cloned with the TOPO TA Cloning kit (Invitrogen Corp., 
San Diego CA USA) following to the manufacturer's protocol. PCR products were purified using the QIAquick PCR purification kit (Qiagen SA, Grenoble, France) following the manufacturer's instructions. Clone libraries were constructed by transforming E. coli TOP10F'. Clones were selected on Petri dishes containing ampicilline $(50 \mu \mathrm{g} / \mathrm{ml})$ and XGAL and IPTG for the white - blue selection. White clones were then cultured and treated for sequencing at the "Ouest Genopole Plateforme" (Roscoff, France, http//www.sbroscoff.fr/SG/) on a Abi prism 3100 GA (Applied Biosystem), using the Big-Dye Terminator V3.1 (Applied Biosystem) following the manufacturer's instructions.

\subsection{Phylogenetic analyses}

To determine approximate phylogenetic affiliations, sequences were compared to those available in databases using the BLAST network service (Altschul et al., 1990). Alignments of 16S rDNA sequences were performed using CLUSTALW (Thompson et al., 1994), further refined manually using SEAVIEW (Galtier et al., 1996). The trees were constructed by PHYLO-WIN (Galtier et al., 1996). Only homologous positions were included in the phylogenetic comparisons. For the $16 \mathrm{~S}$ rDNA phylogenetic reconstruction, the robustness of inferred topology was tested by bootstrap resampling (500) (Felsentein, 1985) of the tree calculated on the basis of evolutionary distance (Neighbor-Joining-algorithm ; Saitou et al., 1987) with Kimura 2 correction. Sequences displaying more than $97 \%$ similarity were considered to be related, and grouped in the same phylotype. Phylogenies of amino acid sequences of the pmoA (154 aa) and APS (129 aa) were reconstructed using PHYLO-WIN with Neighbor-Joining-algorithm and PAM distance (according to Dayhoff's PAM model). The robustness of the inferred topology was tested by bootstrap resampling (500). 
224

Nucleotide sequence accession numbers. Sequences have been deposited at EMBL with

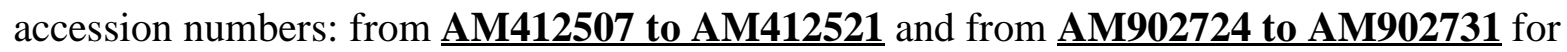

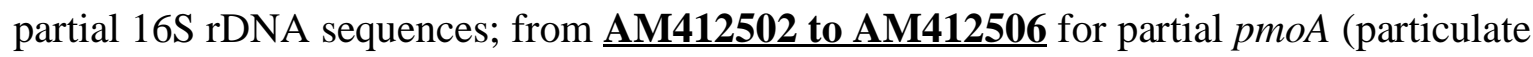
methane monooxygenase subunit A) gene; and from AM902732 to AM902736 for APS reductase gene.

\section{Results}

\subsection{Morphology and ultrastructure of the epibionts}

A total of 315 pictures was analyzed on which 6567 bacterial cells were counted. On in situ reference shrimps, TEM observations of the scaphognathite bacteria revealed more morphological diversity (figure 1) than previously described by Scanning Electron Microscopy (SEM) studies (Segonzac et al., 1993 ; Zbinden et al., 2004).

We observed 3 types of filaments (two thin types and one large) and two types of rods.

Dimensions are in the range of those previously found (table 1). Two types of rods can be distinguished based on size, location and aspect of the intracellular contents. The first type (figure 1b) is characterized by short and thick cells, with a dense dark intracellular content. They are mainly located on the setae. The second type (figure $1 \mathrm{~b}$ ) is longer and thinner, with a light intracellular content. These rods are mainly located on the barbula that emerge from the setae. Two types of thin filaments can be distinguished based on the aspect of the intracellular contents : i) a small number of thin filaments exhibit rectangular cells with no marked narrowing between two adjacent cells. Cells in these filaments show a homogeneous and dense content, with few electron light areas and no granules (figure 1d); ii) the others, more 
numerous, exhibit ovoid-shaped cells, with marked narrowing between two adjacent cells.

Cells of these filaments have a more heterogeneous intracellular content (which seems denser at the periphery and more diffuse in the center) and contain granules (figure 1e).

Ultrastructural changes are observed between the bacteria of re-pressurised shrimps and those of reference shrimps (figure 2). No significant morphological differences were noticed between the bacteria of the shrimps from both pressure experiments. Cells of large and thin filaments, as well as thick rods, have a less regular shape and exhibit a more heterogeneous intracellular content than those of reference shrimps (figure $2 b-c$ ). Only thin rods keep the ultrastructal aspect observed in reference shrimps. Some of the bacteria show a globular intracellular content (figure 2d) or additional membrane folds (figure 2e). These types are only observed among bacteria of the shrimps maintained at 230 bars. Occasionally, these morphotypes can have a very degraded aspect, with totally mis-shapen cells (figure 3a), completely globular cell contents (figure 3c) or cell ghosts (figure 3c). Cell ghosts are also occasionally observed among bacteria of reference shrimps where they represent 1.5 to $4 \%$ of all the bacteria, and may be due to the usual turn-over of the cells. Cells with irregular shape and contents account for up to $30 \%$ of all cells in the re-pressurised shrimps and ghosts up to $15 \%$ (intra-individual variation between the five setae is too high to test the significance of inter-individual variations and the effect of sulfide exposure). Furthermore, very few dividing cells were observed for re-pressurised shrimps, whereas they were numerous for in situ reference shrimps. Surprisingly we observed, for the first time among $R$. exoculata epibionts (in reference shrimps, as well as in re-pressurised ones), some bacteria with stacks of intracytoplasmic membranes typical of methanotrophs (figure 2f) in both reference and repressurised shrimps. 


\subsection{Intracellular electron dense granules}

271

272

273

274

275

Only granules larger than $75 \mathrm{~nm}$ in diameter were considered, the largest measuring up to 200 nm. Spots under $75 \mathrm{~nm}$ were counted separately, as "spots". The number of granules and spots is higher for reference shrimps than for re-pressurised ones (table 2). Granules occurred only in one type of thin filament, and are absent from thick filaments and rods. A given cell may contain several granules and spots (up to 7 granules and 10 spots per cell).

In the reference shrimps, most of the granules appear full (i.e they are electron dense and appear black on micrographs, figure 4a), whereas most appear partially or completely empty for the re-pressurised shrimps (i.e they are electron light and appear, at least partly white on micrographs, figure 4b). Percentage of full granules for each experiment are illustrated on figure 5. The percentage of full granules differs significantly between reference and repressurised shrimps (one-way ANOVA test; $F=76.942, \mathrm{p}<10^{-6}$ ), although no significant difference was detected between sulfide and non-sulfide shrimps at 230 bars (SNK a posteriori test, $\mathrm{p}>0.05)$.

\subsection{Chemical composition of granules}

An EDX microanalysis was performed in order to determine the elemental composition of the granule content (figure 6). The control spectrum from the cytoplasmic area of the bacteria showed copper $(\mathrm{Cu})$ peaks due to the support grid, uranyl $(\mathrm{U})$ peaks due to uranyl acetate staining, and traces of chloride $(\mathrm{Cl})$ due to the epoxy resin. Two types of granules were analyzed. The first type contains 2 main peaks : phosphorus $(\mathrm{P})$ and iron (Fe), in some cases associated with small amounts of calcium (Ca) (not shown). The second type of granules 
shows a single peak of sulfur (S). Occasionally, traces of iron (Fe) are detected (but it can be due to the close occurrence of a thick iron oxide layer that surrounds some bacteria).

\subsection{Preliminary screening of bacterial diversity}

DNA was successfully extracted from scaphognathite and branchiostegite samples. PCR amplifications for Archaea failed regardless of the conditions tested, even with nested PCR. For Bacteria, 69 clones were sequenced for the scaphognathite and 56 for the branchiostegite of an reference shrimp. Only 53 clones sequences were kept for the scaphognathite sample and 46 for the branchiostegite sample, the other clone sequences being too short or of bad quality. No chimera was detected in our study.

All the sequences are related to the Proteobacteria cluster (figure 7), mainly within the Epsilon and Gamma groups, the Alpha and Deltaproteobacteria being less abundant. One group of 19 sequences is related to the $R$. exoculata gut clone 15 , found in a previous study on the gut of a specimen from the same vent site (Zbinden and Cambon-Bonavita, 2003). A second group of 13 sequences is related to sequences retrieved from a vent gastropod coming from Rodriguez Triple junction in the Indian Ocean (Goffredi, 2004). A third group (5 clone sequences) is related to the Rimicaris exoculata epibiont (Polz and Cavanaugh, 1995). Nineteen clones sequences are related to the Rimicaris exoculata gut clone 22 (Zbinden and Cambon Bonavita, 2003). Six clone sequences are related to the Deltaproteobacteria. Twenty four sequences are affiliated to the Gammaproteobacteria. These latter are related to sequences retrieved on a vent gastropod (Goffredi, 2004) and also to clone sequences retrieved on carbonate chimney from the Lost City vent field (Brazelton et al., 2006). The last 
314

315

316

317

318

319

320

321

group comprises eight clones, related to the Alphaproteobacteria, close to Marinosulfomonas methylotropha, and to a clone isolated from Lost City vent field (Brazelton et al., 2006).

\section{5. pmoA and APS sequence analyses}

We successfully amplified the $p m o A$ and APS reductase genes using DNA extracted from the scaphognathite. Fifteen clones were sequenced for the $p m o A$ and 5 for the APS reductase. All the sequences were kept for the phylogenetic analyses. For the $p m o A$ gene (Figure 8), two clone sequences are affiliated to the Methylobacter sp. group, two clones sequences are affiliated to a Bathymodiolus symbiont sequence and 11 clones sequences are affiliated to the Methylomonas methanica. For the APS reductase gene (Figure 9), 5 sequences were related to the Deltaproteobacteria. Ninety sequences were only marginally related to the Gammaproteobacteria APS gene (83\% of similarity) and were related to the Idas thiotrophic clone (Duperron et al. 2008).

As no genes, until now, of the iron-oxidation pathway for neutrophilic iron-oxidizing bacteria are known, this metabolic pathway cannot be investigated by this method.

\section{Discussion}

\subsection{Is sulfide oxidation active in the epibiotic community?}

Transmission electron microscopy allowed us to refine the morphological descriptions of the epibionts on the reference shrimps, detecting two types of thin filaments, and two types of rods, in addition to the thick filaments. These results indicate that the morphological diversity of bacteria associated with $R$. exoculata is higher than previously reported (Casanova et al., 1993; Gebruk et al., 1993 ; Zbinden et al., 2004). The molecular survey supports this 
337

338

339

340

341

342

343

344

result. Even though additionnal sequence investigations are needed to fully describe the microbial diversity within the gill chamber, the present study provides a preliminary overview of the epibiotic community composition. Many Epsilonproteobacteria sequences are related to microbial diversity usually associated with various hydrothermal invertebrates (Alvinella pompejana: Alain et al., 2002; Paralvinella palmiformis: Alain et al., 2004; gastropods: Goffredi et al., 2004; Suzuki et al., 2005; and Rimicaris exoculata gut: Zbinden and CambonBonavita, 2003) and to the MAR environment (Lopez-Garcia et al., 2002). Only five sequences are slightly related to "Rimicaris exoculata ecto-epibiont". The Deltaproteobacteria diversity is restricted to one cluster, and is related to an uncultured bacterium colonizing the mineral surfaces of a sulfide-microbial incubator. These microorganisms are usually thought to play a role in the sulfur cycle. In addition, we obtained APS reductase gene sequences that are related to those of the Desulfobulbaceae (Friedrich, 2002) known to be thiotroph. Most of the APS gene sequences obtained were related to the Idas thiotrophic symbiont gene (Duperron et al., 2008), which is a Gammaproteobacteria, but with a low level of similarity (83\%). In our phylogenetic survey, we did not obtain 16S rDNA gene sequence related to thiotrophic Gammaproteobacteria, so it is unlikely that our APS gene sequences are related to these Gammaproteobacteria. As no Epsilonproteobacteria APS gene sequence is available in databanks, our APS gene sequences are more likely related to the numerous Epsilonproteobacteria identified in the phylogenetic survey. It is noteworthy that the APS gene can be transferred laterally among Bacteria. It is therefore not a good phylogenetic marker (Friedrich, 2002; Meyer and Kuever, 2007). 
Bacteria associated with re-pressurised shrimps exhibit different ultrastructures compared

360

361

362

363

364

365

366

367

to the reference shrimps. A mean of $30 \%$ of the epibionts display what we interpret as a degraded aspect (i.e. heterogeneous or globular cellular content, irregular wall shapes, cell ghosts). In addition, the number of dividing cells is higher for the reference shrimps, indicating a better physiological state. These results could indicate that some of the bacteria cannot withstand the chemical environment of the re-pressurisation experiments, whether or not sulfides are present.

TEM observations of the epibionts reveal the massive occurrence of intracellular granules.

Such granules are often present in prokaryotic organisms (Shively, 1974). They comprise polyglucoside, polyphosphate granules, crystals or paracrystalline arrays such as magnetosomes $\left(\mathrm{Fe}_{3} \mathrm{O}_{4}\right)$, poly- $\beta$-hydroalkanoate (PHA) and sulfur globules. The main roles of these granules are hypothesized to be storage forms of energy and/or of various compounds such as carbon, sulfur and phosphates. They can also play a part in detoxification processes. X-ray analyses indicate that there are two type of granules, one type containing phosphorus (P) and iron (Fe), most probably under polyphosphate form; the other type containing mainly sulfur (S). Several granules can occur in one bacterial cell, but they are always of the same type. The maintenance in a pressurized aquarium lead to the emptying of most of the granules, which suggests a storage role. Addition of sulfide does not affect this emptying phenomenon. However, the granules were counted as a whole, as it was no longer possible to morphologically distinguish the polyphosphate from the sulfur granules. It is conceivable that the slightly higher percentage of full granules, counted in the bacteria that received sulfide pulses (see figure 5), is due to a better conservation of the sulfur granules. $R$. exoculata epibionts (from the Snake Pit site) were hypothesized to acquire their metabolic energy from 
382

383

384

sulfide oxidation. At the ultrastructural level, sulfur-oxidizing bacteria are characterized by the accumulation of large granules of elemental sulfur, which is known to dissolve in solvents like those commonly used for classical TEM preparations (Vetter, 1985). Consequently, these globules appear empty in thin sections (Lechaire et al., 2006). On our sections, the granule contents were not removed during preparation steps, which suggests that they are not elemental sulfur under the form usually found in sulfur-oxidizing bacteria. We can then hypothesize that these granules are rather formed of another type of more stable cristalline sulfur or are sulfur-rich organic matter. Nevertheless, sulfur-containing biopolymers are rare : they are mostly proteins containing methionine and cysteine, or complex polysaccharides that contain sulfate groups. PTE (polythioester), a new class of sulfur-containing polymer, has recently been described, (Lütke-Eversloh et al., 2001). It belongs to the polyhydroxyalkanoates (PHAs), a class of biopolymers known to occur abundantly as storage compounds for energy and carbon, in a large variety of bacteria and archaea (Anderson and Dawes, 1990).

Taken all together, the TEM observations of bacteria associated to re-pressurised shrimps show a low positive impact of sulfide reexposure. Three hypotheses could thus be put forward to explain this: 1) the concentration and frequency of the pulses were insufficient to allow a good maintenance of the epibionts, or 2) these bacteria do not all rely on sulfide for their growth, or 3) the chemical composition of the fluid in the pressure vessel was not adapted for epibiont growth that may require more complex substrates as suggested by the lack of cultures despite many attempts. Considering the results of previous work on the epibionts of R. exoculata (Zbinden et al., 2004) and the chemistry of this peculiar environment : low sulfide but high iron and methane concentration (Charlou et al., 2002; 
Douville et al., 2002), it is possible that some bacteria do not rely on sulfide oxidation but rather on iron or methane oxidation.

\subsection{Occurrence of iron oxidation among the epibiotic community}

Genes involved in iron oxidation at neutral $\mathrm{pH}$ are still unknown and iron oxidizers show a broad diversity among the Proteobacteria (Edwards et al., 2003). So, iron oxidation metabolism could not be studied through a molecular approaches. Nevertheless, iron polyphosphate granules were detected inside the epibiont cells. Polyphosphate granules are widely distributed in prokaryotes, ranging in diameter from $48 \mathrm{~nm}$ to $1 \mu \mathrm{m}$ (Shively, 1974). Putative roles of polyphosphate are numerous : ATP substitute, energy storage or chelator of metal ions (Kornberg, 1995). Lechaire et al. (2002) described the occurrence of iron polyphosphates granules in bacteria associated with the tube of Riftia pachyptila, a hydrothermal vent vestimentiferan. Since polyphosphates are known to fluctuate in response to nutritional and other parameters, these authors suggest that they could act as a reservoir of oxygen in the case of environmental anoxia. As the occurrence of iron-oxidizers among the bacteria has been suggested (Zbinden et al., 2004), these granules could be a reservoir for iron. Alternatively, if these granules occur in non-iron oxidizing bacteria, the chelation of iron by the polyphosphate granules could reduce its toxicity for the cell.

Anyway, the only way to certify the occurrence of iron-oxidizing bacteria among the epibionts is to successfully cultivate and isolate these strains. Such attempts are under progress in our lab. 


\subsection{A possible alternative metabolism : methanotrophy and methylotrophy}

428

429

430

A sixth morphotype, bacteria with stacks of intracytoplasmic membranes typical of type I

methanotrophs, was observed for the first time among $R$. exoculata epibionts. Moreover, our sequences cluster with known Gammaproteobacteria methanotrophic epibionts sequences, such as Bathymodiolus methanotrophic gill symbionts (Duperron et al., 2005). This is also supported by our three groups of pmoA sequences that clearly belong to the methylotrophic Gammaproteobacteria class (Methylomonas sp., Methylobacter sp. and Bathymodiolus pmoA gene sequences). In addition, some clone sequences are related to Alphaproteobacteria methylotroph species and to Epsilonproteobacteria clone sequences retrieved from enrichedmethane environments such as the MAR Lost City and Rainbow sites, or to the Milano mud volcano (Figure 7).

\subsection{Co-occurrence of different metabolic types in the epibiotic community}

Taken all together, our microscopic observations and molecular data indicate that at least three metabolic types could co-occur among the epibiotic microbial community associated to R. exoculata at Rainbow: iron-oxidation, methanotrophy and thiotrophy.

Desbruyères et al. (2001) tried to correlate biological diversity to the varying composition of end-member fluids. According to the amount of iron oxide closely associated to the epibionts (Zbinden et al., 2004), and to the high level of ferrous iron in the pure fluids (Charlou et al., 2002), we suggest that iron oxidation may be the dominant metabolism for this site. Recently, Salerno et al. (2005) correlated the relative microbial abundance of epibiont types of two species of mussels (Bathymodiolus azoricus and B. heckerae) with the availability of $\mathrm{CH}_{4}$ and dissolved $\mathrm{H}_{2} \mathrm{~S}$ in the end-member fluids. They found that when the $\mathrm{CH}_{4}: \mathrm{H}_{2} \mathrm{~S}$ ratio was less 
than 1 (as for Snake Pit, Campbell et al., 1988) then thiotrophic epibionts were dominant. If the ratio was greater than 2 (as for Lost City, Kelley et al., 2001) then methanotrophs were the dominant epibionts. For Rainbow, the ratio of $\mathrm{CH}_{4}: \mathrm{H}_{2} \mathrm{~S}$ varies from 1.54 to 2.61 in pure fluids (Charlou et al., 2002). Applying the Salerno et al. (2005) empirical model to Rimicaris epibionts at Rainbow, would suggest that methanotrophy is an important metabolic pathway, possibly dominating sulfide oxidation. Sampling and in situ measurements in shrimp swarms provide nevertheless a more realistic picture of the environmental conditions experienced by the shrimps. A recent study on potential electron donors for microbial primary production within the swarms at Rainbow indicates that ferrous iron is the most favorable energy source to support epibiotic growth. Methane and sulfide would appear as secondary energy sources in this environment, where hydrogen could also represent an altenative energy source for the epibionts (Schmidt et al., 2008).

\section{Conclusion}

Based on TEM observations, and a preliminary molecular survey, the diversity of the Rimicaris exoculata epibionts (in terms of morphology and metabolism) appears to be higher than previously reported. Based on these results, we propose that the three metabolic types (iron, sulfur and methane oxidation) co-occur within the epibiont biomass associated with Rimicaris exoculata, and that the relative contribution of each metabolism may differ according to the local fluid chemical composition. A much wider scale study, with animals collected from chemically contrasted environments, is needed to better understand the connections of the epibiotic bacterial communities in response to the chemistry of the environment. 
474 Acknowledgements. The authors wish to thank P.M. Sarradin, chief scientist of the ATOS

475 cruise, as well as the captain and crew of the R/V Atalante and the Victor ROV team. The

476 authors also thank Eric Thiébaut for his help with the statistical analyses, and Philippe

477 Compère for his help in determination of the moulting stages. The authors are also grateful to

478 Stephane Hourdez for his review of the manuscript. Electron microscopy was performed at

479 the Service de Microscopie Electronique, IFR 83 de Biologie Integrative-CNRS/Paris VI.

480 This work was partly funded with the help of the MOMARNET and VENTOX (EVK3 CT-

481 1999-0003) programs, Ifremer research institute and Région Bretagne and Ouest Génopole. 


\section{References}

Alain, K., Olagnon, M., Desbruyères, D., Page, A., Barbier, G., Juniper, K., Quérellou, J., Cambon-Bonavita, M., 2002. Phylogenetic characterization of the bacterial assemblage associated with the hydrothermal vent polychaete Paralvinella palmiformis. FEMS Microbiol. Ecol. 42, 463-476.

Alain, K., Zbinden, M., Le Bris, N., Lesongeur, F., Querellou, J., Gaill, F., Cambon-Bonavita, M.-A., 2004. Early steps of colonisation processes at deep-sea hydrothermal vents. Environ. Microbiol. 6 (3), 227-241.

Altschul, S., Gish, W., Miller, W., Myers, E., Lipman, D., 1990. Basic local alignment search tool. J. Mol. Biol. 215, 403-410.

Anderson, A., Dawes, E., 1990. Occurence, metabolism, metabolic role, and industrial uses of bacterial polyhydroxyalkanoates. Microbiol. Rev. 54(4), 450-472.

Blazejak, A., Erseus, C., Amann, R., Dubilier, N., 2005. Coexistence of bacterial sulfide oxidizers, sulfate reducers, and spirochetes in a gutless worm (Oligochaeta) from the Peru margin. Appl. Environ. Microbiol. 71, 1553-1561.

Brazelton, W., Schrenk, M., Kelley, D., Baross, J., 2006. Methane- and sulfur-metabolizing microbial communities dominate the Lost City hydrothermal field ecosystem. Appl. Environ.

Microbiol. 72 (9), 6257-6270.

Campbell, A., Palmer, M., Klinkhammer, G., Bowers, T., Edmond, J., Lawrence, J., Casey, J., Thompson, G., Humphris, S., Rona, P., Karson, J., 1988. The chemistry of springs on the Mid-Atlantic Ridge. Nature 335, 514-519.

Casanova, B., Brunet, M., Segonzac, M., 1993. L'impact d'une épibiose bactérienne sur la morphologie fonctionnelle de crevettes associées à l'hydrothermalisme médio-Atlantique. Cah. Biol. Mar. 34, 573-588. 
Charlou, J. L., Donval, J. P., Fouquet, Y., Jean-Baptiste, P., Holm, N., Caccavo, F., 2002.

Geochemistry of high $\mathrm{H}_{2}$ and $\mathrm{CH}_{4}$ vent fluids issuing from ultramafic rocks at the Rainbow hydrothermal field (36²14'N, MAR). Chem. Geol. 191, 345-359.

Desbruyères, D., Biscoito, M., Caprais, J. C., Colaço, A., Comtet, T., Crassous, P., Fouquet, Y., Khripounoff, A., Le Bris, N., Olu, K., Riso, R., Sarradin, P. M., Segonzac, M., Vangriesheim, A., 2001. Variations in deep-sea hydrothermal vent communities on the MidAtlantic Ridge near the Azores plateau. Deep-sea Res. PtI 48, 1325-1346.

Douville, E., Charlou, J. L., Oelkers, E. H., Bienvenu, P., Jove Colon, C. F., Donval, J. P., Fouquet, Y., Prieur, D., Appriou, P., 2002. The rainbow vent fluids (36²'N, MAR): the influence of ultramafic rocks and phase separation on trace metal content in Mid-Atlantic Ridge hydrothermal fluids. Chem. Geol. 184, 37-48.

Drach, P., Tchernigovtzeff, C., 1967. Sur la méthode de détermination des stages d'intermue et son application générale aux Crustacés. Vie Milieu 18A, 595-609.

Duperron, S., Nadalig, T., Caprais, J., Sibuet, M., Fiala-Médioni, A., Amann, R., Dubilier, N., 2005. Dual symbiosis in a Bathymodiolus sp. mussel from a methane seep on the Gabon continental margin (Southeast Atlantic): 16S rRNA phylogeny and distribution of the symbionts in gills. Appl. Environ. Microbiol. 71(4), 1694-1700.

Duperron, S., Fiala-Médioni, A., Caprais, J. C., Olu, K., Sibuet, M., 2007. Evidence for chemoautotrophic symbiosis in a Mediterranean cold seep clam (Bivalvia: Lucinidae): comparative sequence analysis of bacterial 16S rRNA, APS reductase and RubisCO genes. FEMS Microbiol. Ecol. 59(1), 64-70.

Duperron, S., Halary, S., Lorion, J., Sibuet, M., Gaill, F., 2008. Unexpected co-occurrence of six bacterial symbionts in the gills of the cold seep mussel Idas sp. (Bivalvia: Mytilidae). Environ. Microbiol. 
530 Edwards, K., Rogers, D., Wirsen, C., McCollom, T., 2003. Isolation and characterization of

novel psychrophilic, neutrophilic, Fe-oxidizing, chemolithoautotrophic a- and g-

Proteobacteria from the deep-sea. Appl. Environ. Microbiol. 69 (5), 2906-2913.

Felsentein, J., 1985. Confidence limits on phylogenies: an approach using the bootstrap. Evolution 30, 783-791.

Friedrich, M., 2002. Phylogenetic analysis reveals multiple lateral transfers of adenosine-5'phosphosulfate reductase genes among sulfate-reducing microorganisms. J. Bacteriol. 1 (1), 278-289.

Galtier, N., Gouy, M., Gautier, C., 1996. SEAVIEW and PHYLO_WIN: two graphic tools for sequence alignment and molecular phylogeny. Comput. Appl. Biosci. 12, 543-548.

Gebruk, A., Pimenov, N., Savvichev, A., 1993. Feeding specialization of bresiliid shrimps in the TAG site hydrothermal community. Mar. Ecol. Prog. Ser. 98, 247-253.

Goffredi, S., Waren, A., Orphan, V., Van Dover, C., Vriejenhoek, R., 2004. Novel forms of structural integration between microbes and a hydrothermal vent gastropod from the Indian Ocean. Appl. Environ. Microbiol. 70 (5), 3082-3090.

Kelley, D., Karson, J., Blackman, D., Früh-Green, G., Butterfield, D., Lilley, M., Olson, E., Schrenk, M., Roe, K., Lebon, G., Rivizzigno, P., Party, t. A.-S., 2001. An off-axis hydrothermal vent field near the Mid-Atlantic Ridge at $30^{\circ} \mathrm{N}$. Nature 412, 145-149. Kornberg, A., 1995. Inorganic polyphosphate : toward making a forgotten polymer unforgettable. J. Bacteriol. 177 (3), 491-496.

Lechaire, J. P., Shillito, B., Frébourg, G., Gaill, F., 2002. Elemental characterization of microorganism granules by EFTEM in the tube wall of a deep-sea vent invertebrate. Biol. Cell 94, 243-249.

Lechaire, J., Frébourg, G., Gaill, F., Gros, O., 2006. In situ localization of sulphur in the 
554

555

556

557

558

559

560

561

562

563

564

565

566

567

568

569

570

571

572

573

574

575

576

577

thiotrophic symbiotic model Lucina pectinata (Gmelin, 1791) by cryo-EFTEM microanalysis. Biol. Cell 98, 163-170.

Lopez-Garcia, P., Gaill, F., Moreira, D., 2002. Wide bacterial diversity associated with tubes of the vent worm Riftia pachyptila. Environ. Microbiol. 4(4), 204-215.

Lütke-Eversloh, T., Bergander, K., Luftman, H., Steinbüchel, A., 2001. Identification of a new class of biopolymer : bacterial synthesis of a sulfur-containing polymer with thioester linkages. Microbiology 147, 11-19.

Meyer, B., Kuever, J., 2007. Molecular analysis of the diversity of sulfate-reducing and sulfur-oxidizing prokaryotes in the environment using aprA as functional marker gene. Appl. Environ. Microbiol. Published online ahead of print on 5 October 2007. Doi: 10.1128 /

AEM.01272-07

Polz, M., Cavanaugh, C., 1995. Dominance of one bacterial phylotype at a Mid-Atlantic Ridge hydrothermal vent site. Proc. Natl. Acad. Sci. USA 92, 7232-7236.

Polz, M., Robinson, J., Cavanaugh, C., Van Dover, C., 1998. Trophic ecology of massive shrimp aggregations at a mid-Atlantic Ridge hydrothermal vent site. Limnol. Oceanogr. 43(7), 1631-1638.

Pond, D., Dixon, D., Bell, M., Fallick, A., Sargent, J., 1997. Occurence of 16:2(n-4) and 18:2 (n-4) fatty acids in the lipids of the hydrothermal vent shrimps Rimicaris exoculata and Alvinocaris markensis: nutritional and trophic implications. Mar. Ecol. Prog. Ser. 156, 167174.

Ravaux, J., Gaill, F., Le Bris, N., Sarradin, P. M., Jollivet, D., Shillito, B., 2003. Heat-shock response and temperature resistance in the deep-sea vent shrimp Rimicaris exoculata. J. Exp. Biol. 206, 2345-2354.

Rieley, G., Van Dover, C., Hedrick, D., Eglinton, G., 1999. Trophic ecology of Rimicaris 
exoculata: a combined lipid abundance/stable isotope approach. Mar. Biol. 133, 495-499. Saitou, M., Nei, M., 1987. The neighbor-joining method : a new method for reconstructing phylogenetic trees. Mol. Biol. Evol. 4, 406-425.

Salerno, L., Macko, S., Hallam, S., Bright, M., Won, Y., McKiness, Z., Van Dover, C., 2005. Characterization of symbiont populations in life history stages of mussels from chemosynthetic environments. Biol. Bull. 208, 145-155.

Schmidt, C., Vuillemin, R., Le Gall, C., Gaill, F., Le Bris, N., 2008. Geochemical energy sources for microbial primary production in the environment of hydrothermal vent shrimps. Mar. Chem. 108(1), 18-31.

Segonzac, M., de Saint-Laurent, M., Casanova, B., 1993. L'énigme du comportement trophique des crevettes Alvinocarididae des sites hydrothermaux de la dorsale médioatlantique. Cah. Biol. Mar. 34, 535-571.

Shillito, B., Jollivet, D., Sarradin, P. M., Rodier, P., Lallier, F., Desbruyères, D., Gaill, F., 2001. Temperature resistance of Hesiolyra bergi, a polychaetous annelid living on vent smoker walls. Mar. Ecol. Prog. Ser. 216, 141-149.

Shively, J., 1974. Inclusion bodies in prokaryotes. Annu. Rev. Microbiol. 28, 167-187.

Suzuki, Y., Sasaki, T., Suzuki, M., Nogi, Y., Miwa, T., Takai, K., Nealson, K., Horikoshi, K., 2005. Novel chemoautotrophic endosymbiosis between a member of the epsilonproteobacteria and the hydrothermal-vent gastropod Alviniconcha aff. hessleri (Gastropoda: Provannidae) from the Indian Ocean. Appl. Environ. Microbiol. 71(9), 5440-5450.

Thompson, J., Higgins, D., Gibson, T., 1994. CLUSTAL W : improving the sensitivity of progressive multiple sequence alignment through sequence weighting, position-specific gap penalties and weight matrix choice. Nucleic Acids Res. 22, 4673-4680.

Van Dover, C., Fry, B., Grassle, J., Humphris, S., Rona, P., 1988. Feeding biology of the shrimp Rimicaris exoculata at hydrothermal vents on the Mid-Atlantic Ridge. Mar. Biol. 98, 
603

604

605

606

607

608

609

610

611

612

613

614

615

616

617

209-216.

Vetter, R., 1985. Elemental sulfur in the gills of three species of clams containing chemoautotrophic symbiotic bacteria: a possible inorganic energy storage compound. Mar.

Biol. 88, 33-42.

Williams, A., Rona, P., 1986. Two new caridean shrimps (Bresiliidae) from a hydrothermal field on the Mid-Atlantic Ridge. J. Crustacean Biol. 6(3), 446-462.

Wirsen, C., Jannasch, H. W., Molyneaux, S., 1993. Chemosynthetic microbial activity at MidAtlantic Ridge hydrothermal vent sites. J. Geophys. Res. 98 (B6), 9693-9703.

Zbinden, M., Cambon-Bonavita, M.-A., 2003. Occurence of Deferribacterales and Entomoplasmatales in the deep-sea shrimp Rimicaris exoculata gut. FEMS Microbiol. Ecol. 46, 23-30.

Zbinden, M., Le Bris, N., Gaill, F., Compère, P., 2004. Distribution of bacteria and associated minerals in the gill chamber of the vent shrimp Rimicaris exoculata and related biogeochemical processes. Mar. Ecol. Prog. Ser. 284, 237-251. 
617

618

619 Figure 1: Bacteria associated with a scaphognathite seta of a reference shrimp. a) General

620

621

622

623

624

625

626

627

628

629

630

631

632

633

634

635

636

\section{Figure legends}

view of the seta (s) and the associated bacteria. b to e) Observed morphotypes: b) rods type (1) attached to the seta (s) and rods type (2) attached to the barbula (ba); c) large filaments; e) thin filaments without granules inside the cells ; d) thin filaments with granules. Scale bars: a $=5 \mu \mathrm{m}, \mathrm{b}, \mathrm{c}, \mathrm{d}, \mathrm{e}=1 \mu \mathrm{m}$.

4

Figure 2: Bacteria associated with a scaphognathite seta of the re-pressurised shrimps. a)

General view of the seta and the associated bacteria. b to e) Observed ultrastructural modifications: b) type 1 rods (type 2 does not seem to be affected); c) large filaments with heterogeneous content; d) or with globular content; e) thin filaments with heterogeneous content (d), and occasionally occurrence of membrane folds at the boundary of the cell (arrows). (f) methanotrophic bacteria characterized by their stacks of intracytoplasmic membranes. Scale bars: $\mathrm{a}=5 \mu \mathrm{m} ; \mathrm{b}=0.5 \mu \mathrm{m} ; \mathrm{c}, \mathrm{d}, \mathrm{e}, \mathrm{f}=1 \mu \mathrm{m}$. 2

Figure 3: Evolution of the morphotypes observed in the re-pressurised shrimps. Filament cells exhibit a mis shapen aspect (a), a completely globular content (b) or appear as ghosts (c).

Scale bars: $\mathrm{a}=1 \mu \mathrm{m} ; \mathrm{b}, \mathrm{c}=0.5 \mu \mathrm{m}$ 
637 Figure 4: Bacterial intracellular granules. Granules are full (arrows) in bacteria associated

638 with the reference shrimp (a) and mostly empty (arrows) in those associated with re-

639 pressurised shrimps (b). Scale bars: $a, b=0.5 \mu \mathrm{m}$.

640

641 Figure 5: Percentage of full granules in bacteria according to treatment. Diagram showing the 642 percentage of full granules per seta for in situ reference shrimp, and re-pressurised shrimps 643 either in seawater or submitted to sulfide pulses. The mean percentage for each treatment is 644 also given.

Figure 6: Elemental X-ray microanalyzes of the bacterial intracellular granules. Spectra were

647

648

649

650

651

652

653

654

655

656

657

658 obtained on a) the cytoplasm of the bacteria (as control), b) the first type of granule showing major $\mathrm{Fe}$ and $\mathrm{P}$ peaks and traces of $\mathrm{Si}, \mathrm{c}$ ) the second type of granule, showing one major $\mathrm{S}$ peak.

Figure 7: Phylogenetic trees obtained using Neighbor-Joining analysis with bootstrap resampling (500 replicates). Topologies were confirmed with Maximum Parsimony method. Bootstrap values are indicated on nodes above $70 \%$. Accession numbers of the sequences used are indicated on the tree (from AM412507 to AM412521 and from AM902724 to AM902731).

Figure 8: Neighbor-Joining tree of pmoA amino acid sequences from Rimicaris exoculata gill chamber epibionts based on 154 amino acid positions using PAM distance (according to 
659 Dayhoff's PAM model). The robustness of the inferred topology was tested by bootstrap 660 resampling (500). Accession numbers of the sequences used are indicated on the tree (from 661 AM412502 to number AM412506).

662

663 Figure 9: Neighbor-Joining tree of APS reductase amino acid sequences from Rimicaris 664 exoculata gill chamber epibionts based on 129 amino acid positions using PAM distance 665 (according to Dayhoff's PAM model). The robustness of the inferred topology was tested by 666 bootstrap resampling (500). Accession numbers of the sequences used are indicated on the $\mathbf{6 6 7}$ tree (from AM902732 to AM902736).

668 
668

669

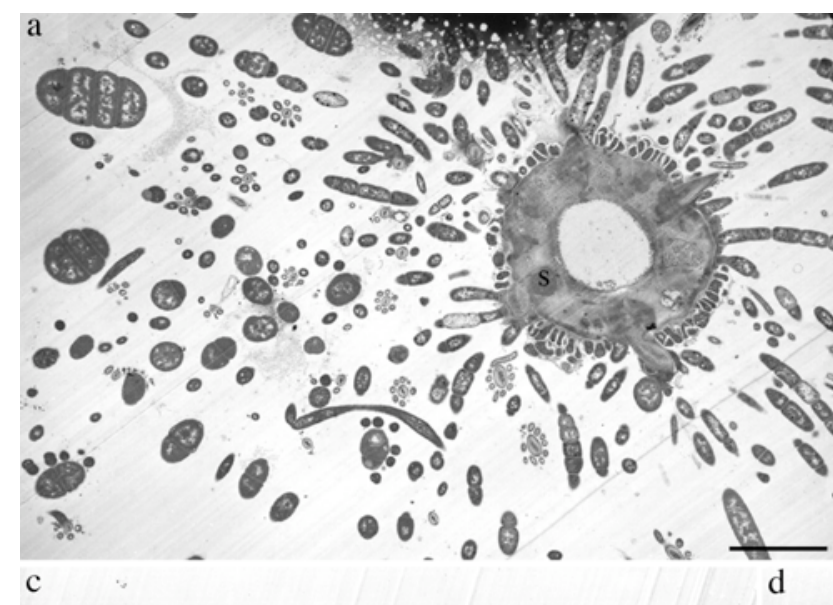

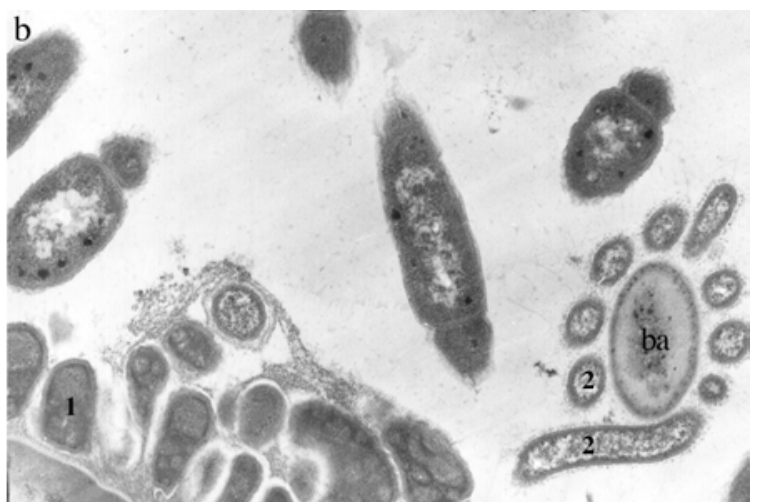
政

gos ?

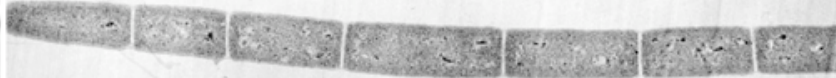

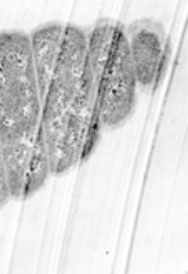
e $-4 \%$ 
671

672

673

674
Figure 2

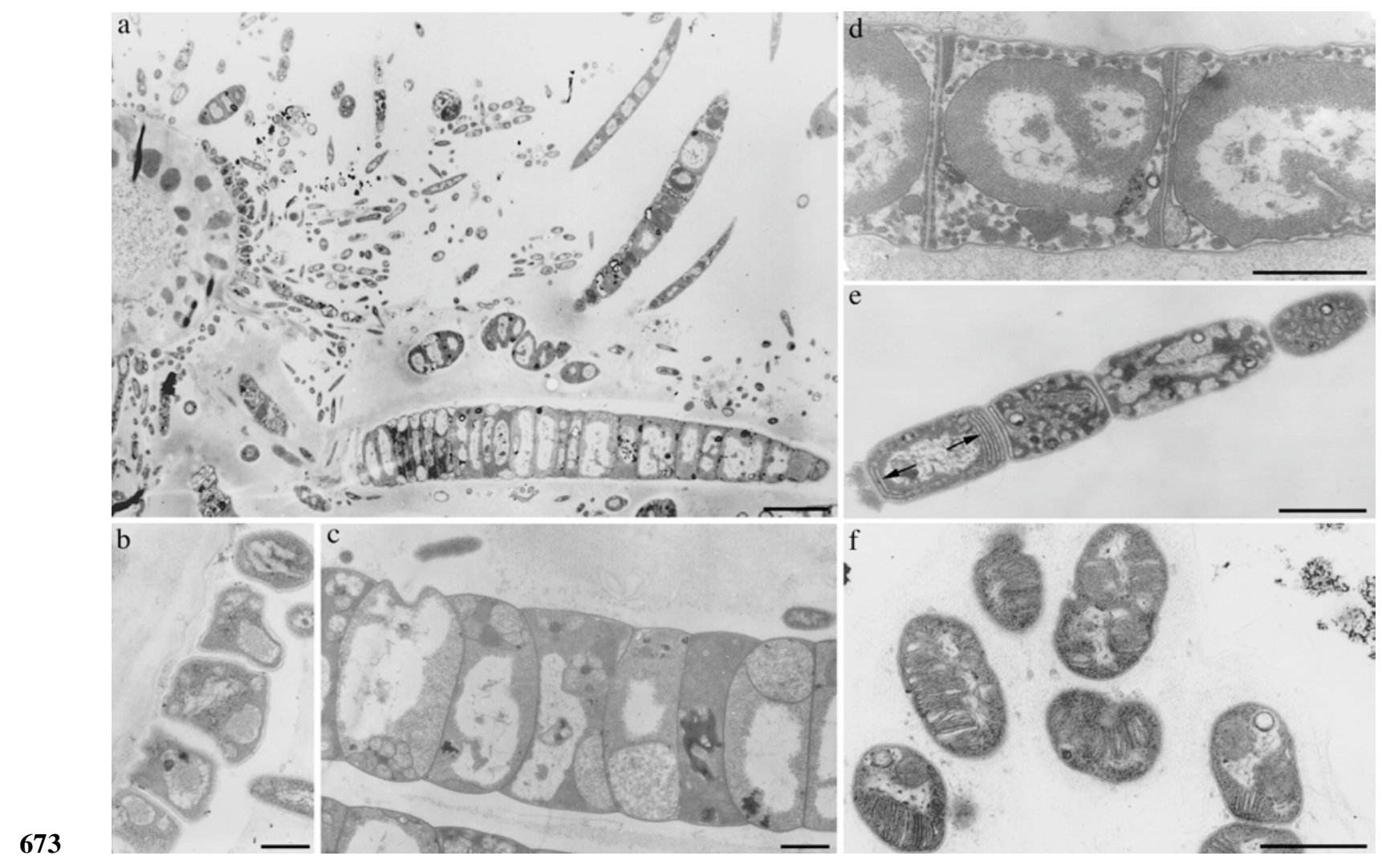


$674 \quad$ Figure 3

675

676
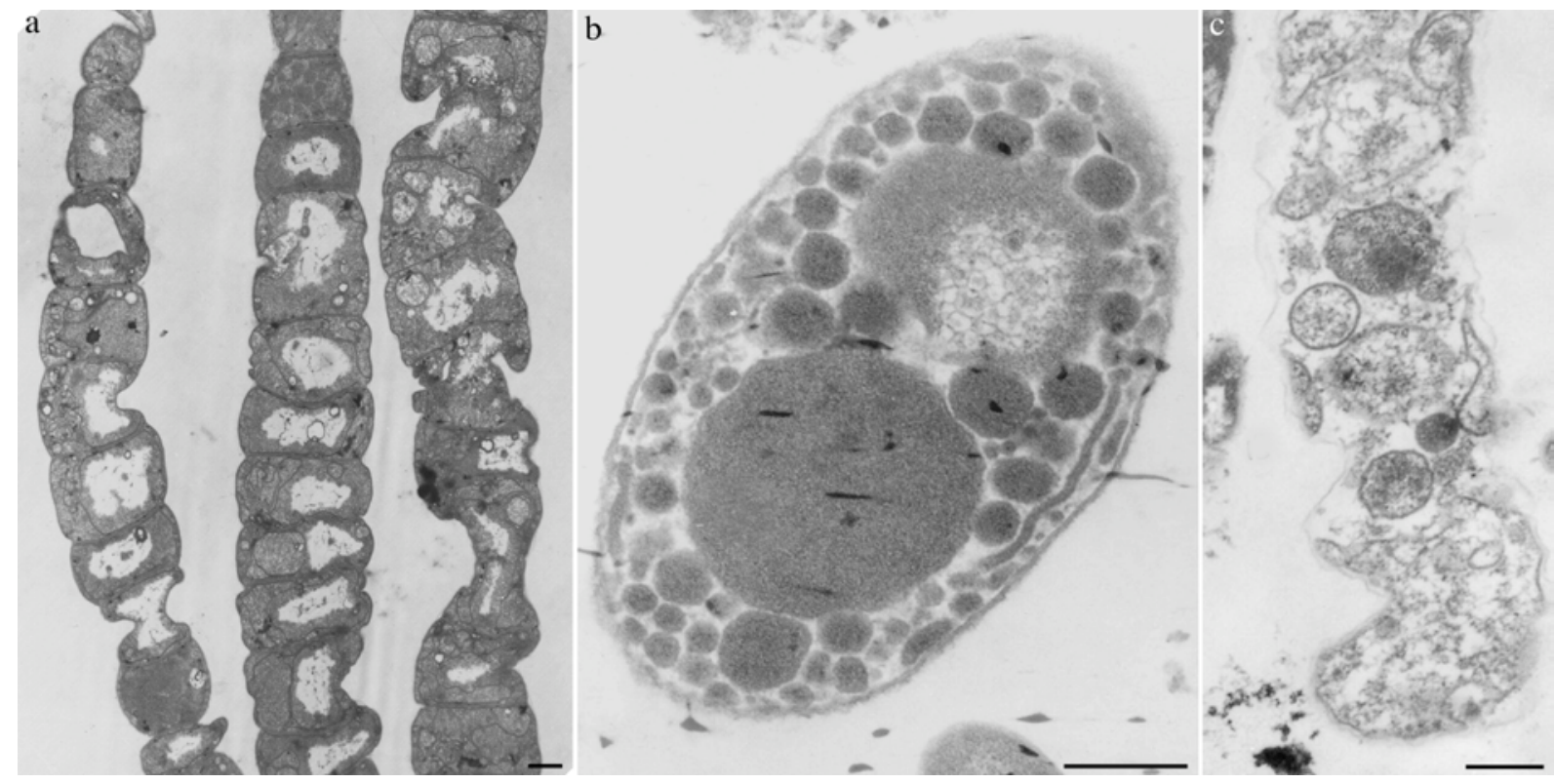

677 
677

678

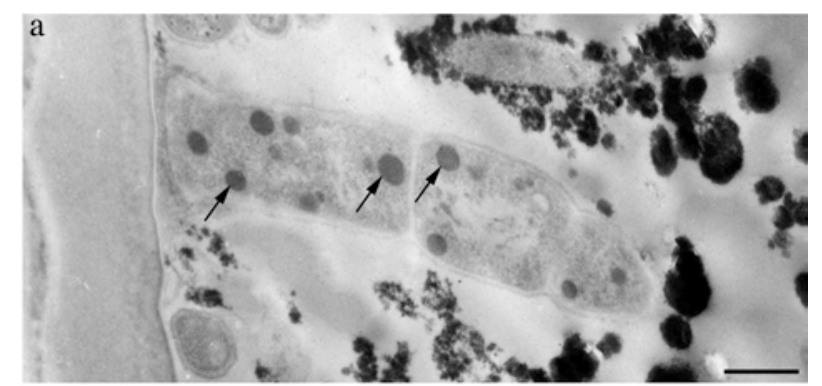

$$
\text { b }
$$

679

680

Figure 4

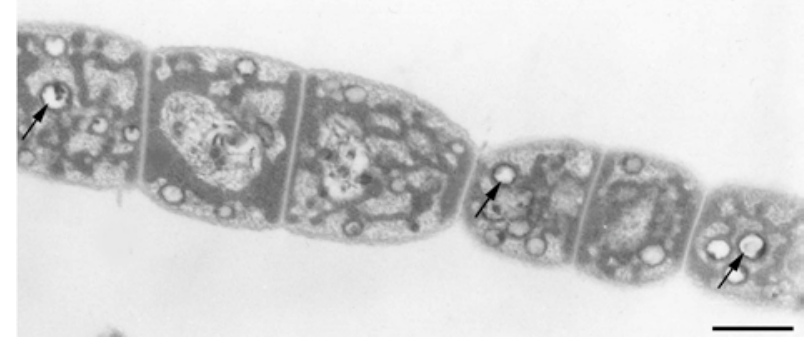


680

681

682

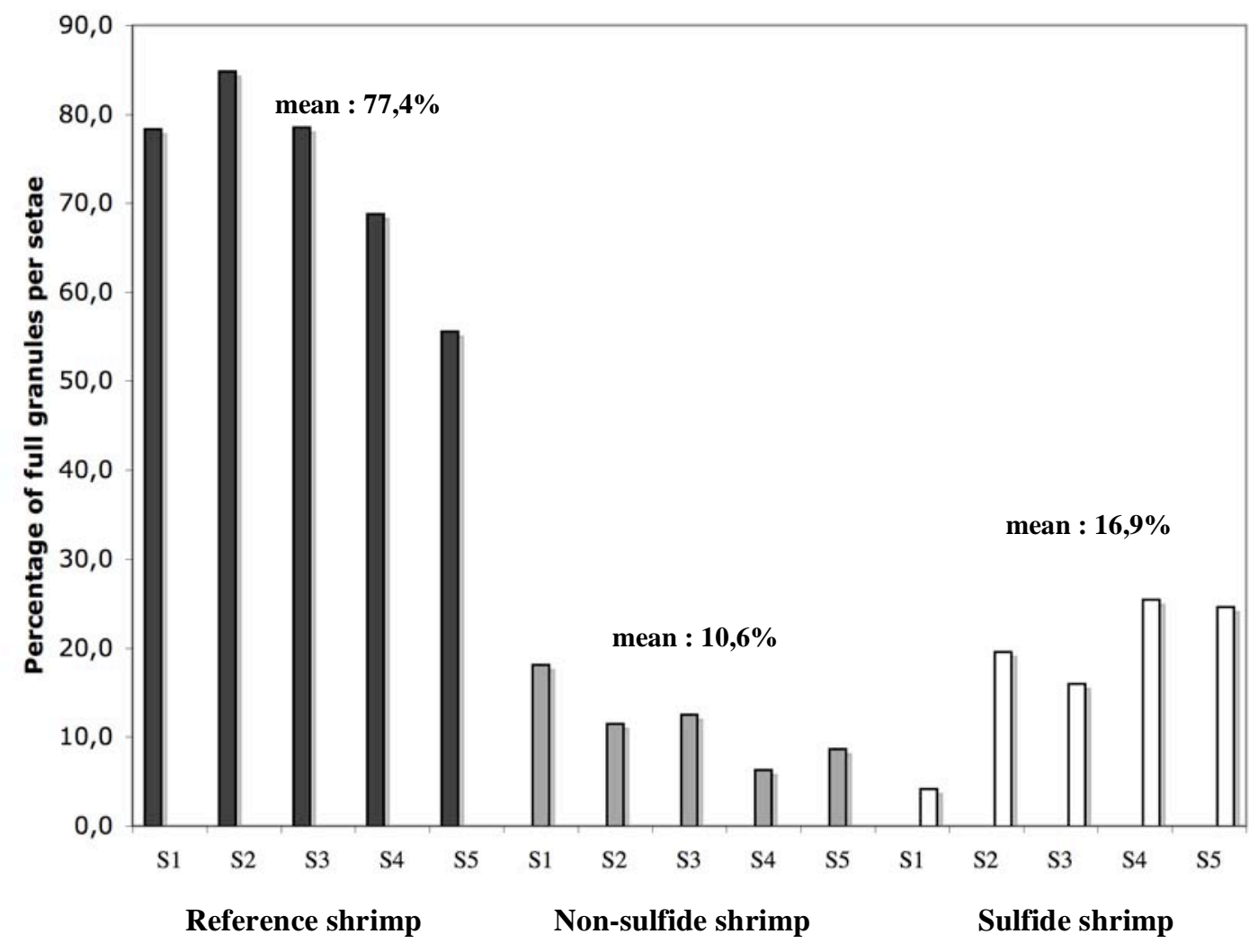


685

686
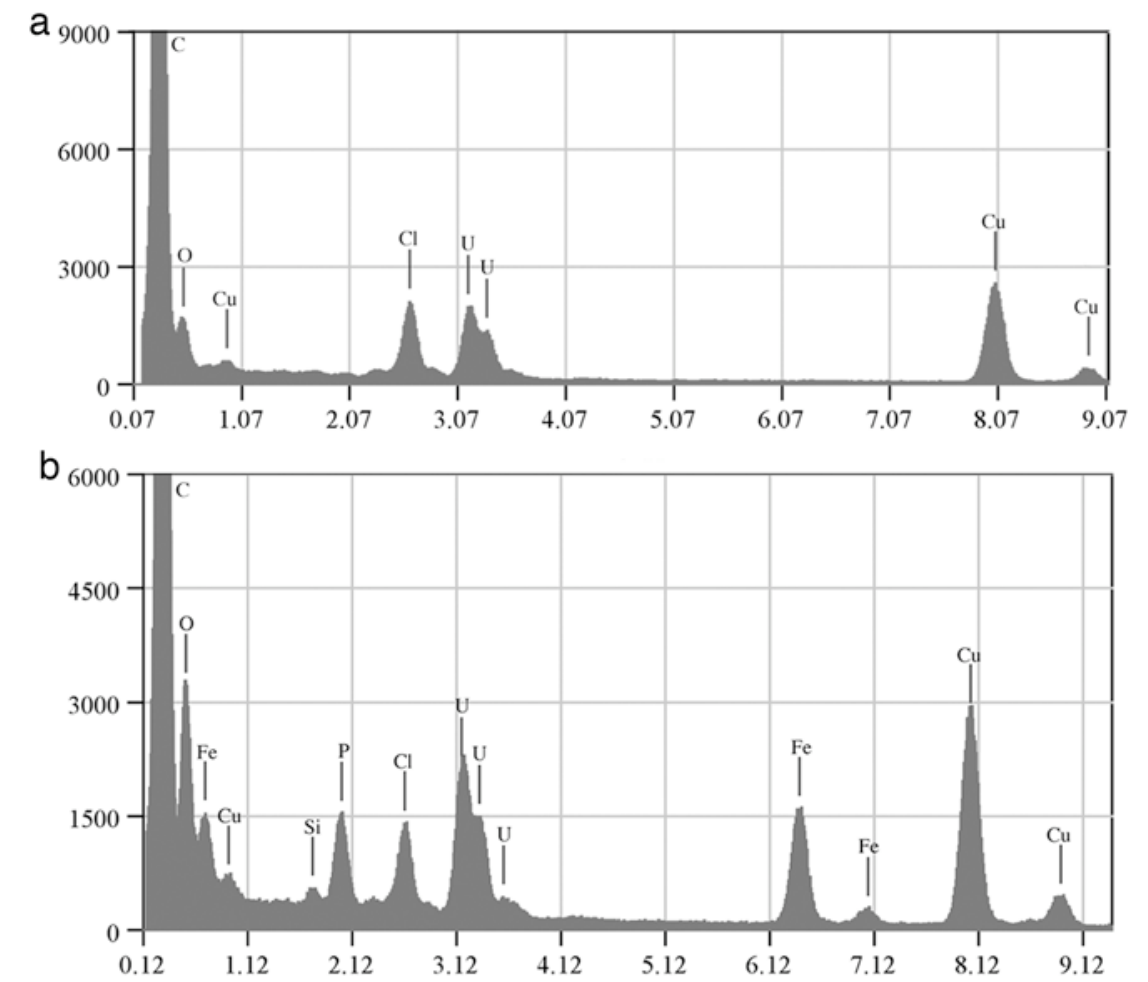

$\mathrm{C}_{8}$

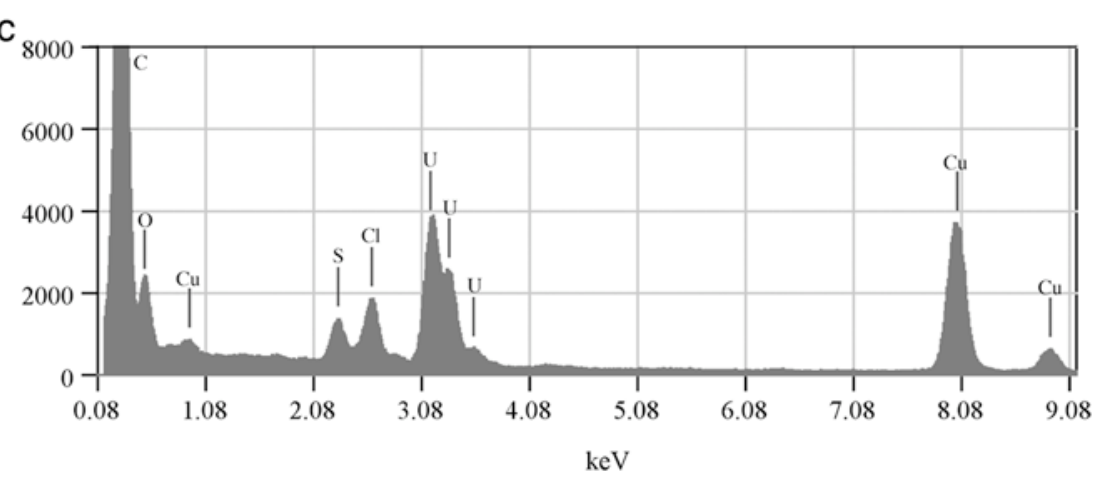

687

688

Figure 6 


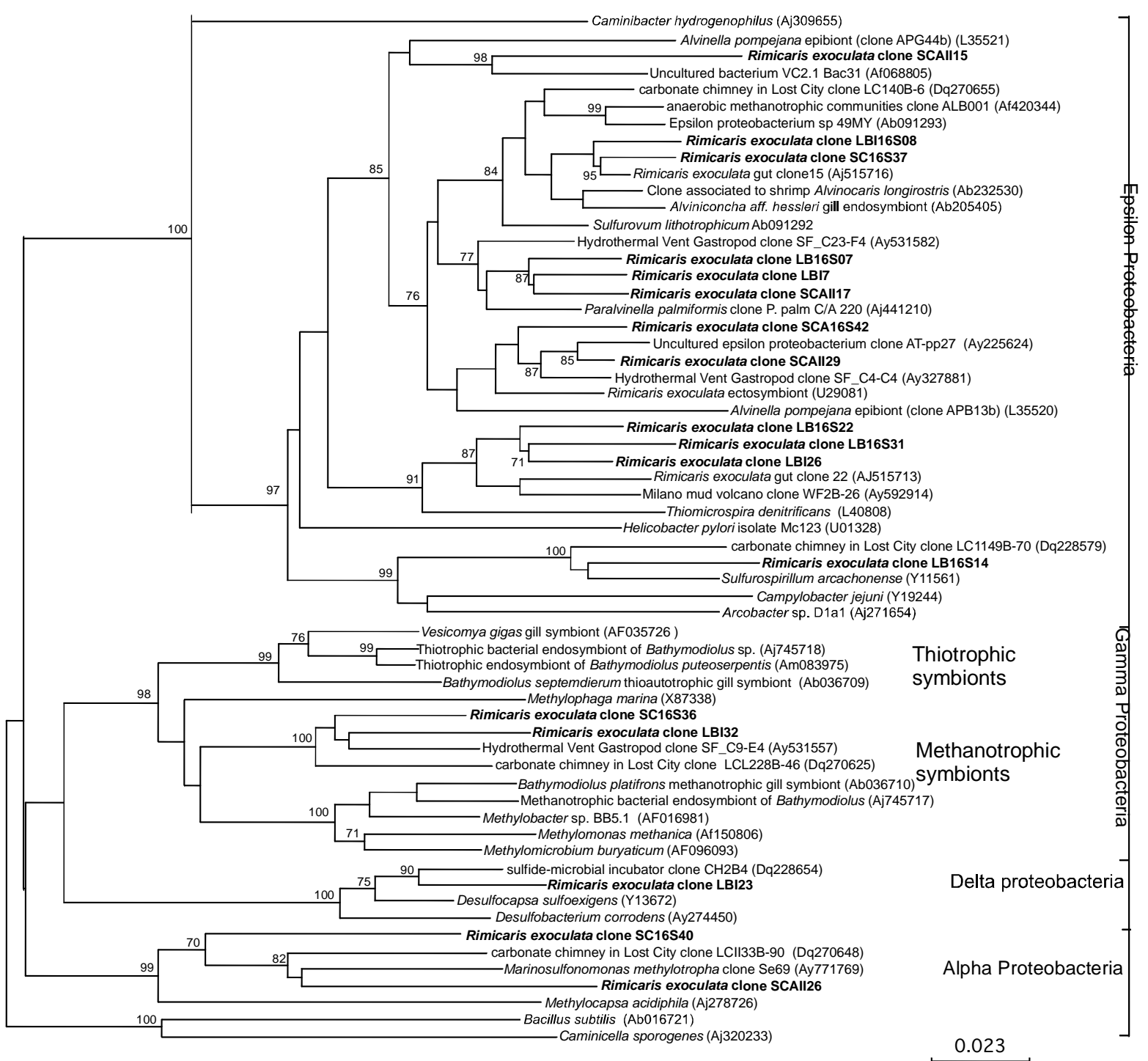


692

693

Figure 8

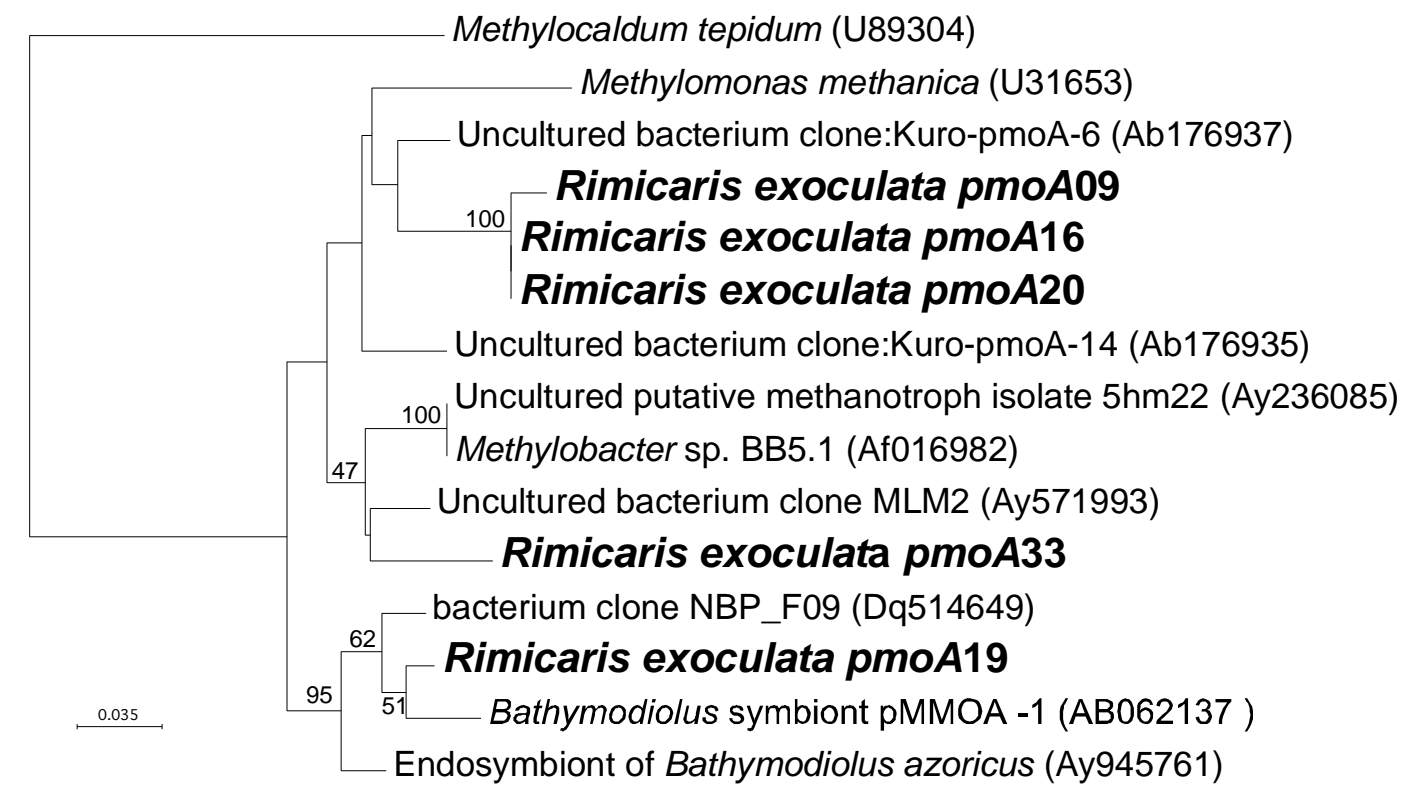


Figure 9

696

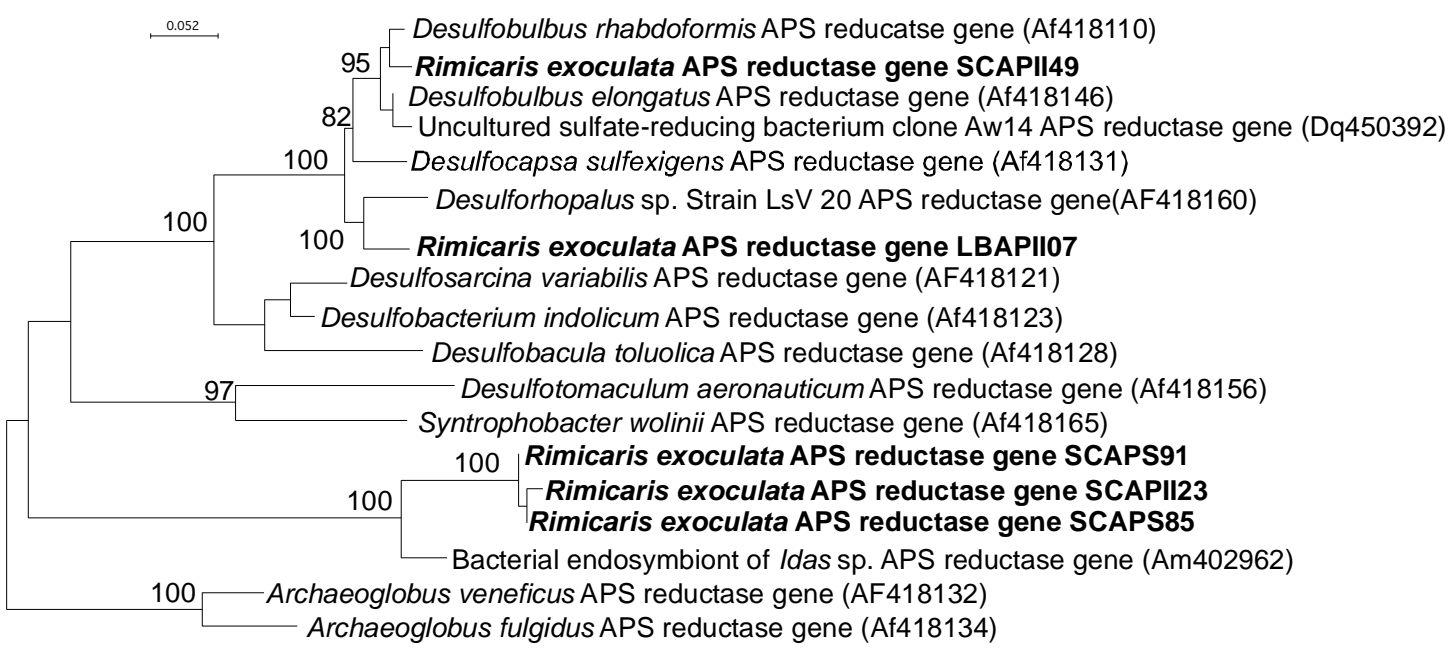

